\title{
SYNTHESIS AND ANTIBACTERIAL ACTIVITIES OF SUGAR-CONTAINING PLATINUM ETHYNYL COMPLEXES
}

\author{
RATAN KUMAR PAUL ${ }^{1}$, MD. FARUAK AHMAD, MOHAMMAD MIZANUR \\ RAHMAN KHAN AND MUHAMMAD YOUNUS*
}

Department of Chemistry, Shahjalal University of Science and Technology, Sylhet-3114, Bangladesh

\begin{abstract}
New sugar-containing aryl ethynyl ligand [ $N$-(4-trimethylsilylethynylphenyl)- $\beta$-D-glucopyranosylamine] 2 has been prepared by the reaction of [ $N$-(4-iodophenyl)- $\beta$-D-glucopyranosylamine] 1 with trimethysilylacetylene in the presence of $\mathrm{Pd}(\mathrm{OAc})_{2} / \mathrm{CuI}$ catalyst, in ${ }^{\mathrm{i}} \mathrm{Pr}_{2} \mathrm{NH}$ and $\mathrm{DMF}$ solvent mixture. The trimethylsilyl group of compound 2 was deprotected using $\mathrm{K}_{2} \mathrm{CO}_{3}$ in methanol to form terminal ethynylene ligand $[N-(\beta$-D-glucopyranosyl)aniline-4-ethyne] 3. Novel platinum mono-ethynyl complex trans- $\left[\left(\mathrm{P}(\mathrm{Bu})_{3}\right)_{2} \mathrm{PtCl}\left(\mathrm{C} \equiv \mathrm{C}-4-\mathrm{C}_{6} \mathrm{H}_{4}-\mathrm{NH}-\mathrm{D}\right.\right.$-glocose $\left.)\right] \mathbf{4}$ and bis-ethynyl complex trans- $\left[\left(\mathrm{P}(\mathrm{Bu})_{3}\right)_{2} \mathrm{PtCl}\left(\mathrm{C} \equiv \mathrm{C}-4-\mathrm{C}_{6} \mathrm{H}_{4}-\mathrm{NH}-\mathrm{D} \text {-glocose }\right)_{2}\right] \mathbf{5}$ were formed by the dehydrohalogenation reaction of trans- $\left[\mathrm{Pt}\left(\mathrm{P}(\mathrm{Bu})_{3}\right)_{2} \mathrm{Cl}_{2}\right]$ with terminal ethynyl ligand 3 in ${ }^{\mathrm{i}} \mathrm{Pr}_{2} \mathrm{NH} / \mathrm{THF}$, in the presence of $\mathrm{CuI}$, at $65^{\circ} \mathrm{C}$. The complexes are hygroscopic in air, and are fairly soluble in methanol and $\mathrm{CH}_{2} \mathrm{Cl}_{2}$. The new compound $\mathbf{2}$ - $\mathbf{5}$ were characterized by FTIR and UV-Vis spectroscopy and elemental analysis. The compounds were tested for antibacterial activity using disk diffusion technique. The platinum complexes $\mathbf{4}$ and $\mathbf{5}$ displayed good resistivity against the following bacteria: Escherichia coli, Proteus penneri, Klebsiella oxytoca and Pseudomonas aeruginosa.
\end{abstract}

Key words: Sonogashira coupling, Dehydrohalogenation, Sugar-containing platinum acetylide, Antibacterial activity

\section{INTRODUCTION}

Arylene ethynylene is an important building block for conjugated organic and organometallic complexes and polymers (Long et al. 2003, Bunz 2009). Conjugated organic polymers (poly (aryleneethynylene)s, PPEs) are semiconductors. These are stable and emissive, and for their fluorescent properties, they can be used as sensors to detect metals, proteins, bacteria and DNA (Bunz 2009, Disney et al. 2004). Introduction of metals (Pt, Pd, Fe, Ru, Os) into the arylene ethynylene may introduce redox, magnetic, optical, and electronic properties in the materials. As a consequence, these materials possess interesting properties such as optical nonlinearity, luminescence, liquid crystallinity (Long et al. 2003). Compared to the application of conjugated organic PPEs

* Corresponding author: <myounus-che@ sust.edu>.

${ }^{1}$ Department of Chemistry, Pabna University of Science and Technology, Pabna-6600, Bangladesh. 
in biology (Kim et al. 2007, Yang et al. 2005, Dam et al. 2002, Phillips 2008, Babudri et al. 2003, Erdogan et al. 2002), little attention is given to their organometallic analogues (Wong et al. 2004, Ma et al. 2005). However, metal coordination complexes with tunable properties, such as radioactivity, cytotoxicity or photophysical features, would be good candidates for biomedical application, e.g. diagnostic tracers or therapeutic agents (Gottschaldt et al. 2009).

To design materials for biological applications, along with the designated properties such as fluorescence and photoactivity, it is necessary to improve the solubility and biocompatibility. One general principle used in nature is the attachment of biomolecules to active species to obtain binding domains, transport systems and enzyme activities. Monosaccharides are fundamental biomolecules, and they are the constitutional parts of complex lipids (glycolipids) and proteins (glycoproteins) and nucleic acid (Steinborn et al. 2000). The attachment of glycosidically bound carbohydrate moieties to metal ions may be a suitable option to create new materials with combined properties of both building blocks: carbohydrates and metal complexes (Wegner et al. 2001, Gottschaldt et al. 2009, Gottschaldt et al. 2004). Sugar fragments can be bound to metal centres either directly or through other atoms in the periphery. Introduction of sugar atom into the biological materials not only increases the solubility, but also influences their biocompatibility, primarily, acting as energy source and contributing to various recognition or specific transformation processes. Carbohydrate complexes of platinum group metals ( $\mathrm{Pd}, \mathrm{Pt}, \mathrm{Rh}, \mathrm{Ir}$ ), where carbohydrate is directly bonded to metal atom, have been reported (Steinborn et al. 2000). In recent years, metal coordination complexes with sugar substituted chelating ligands were studied for the development of diagnostic tracers (Mindt et al. 2006, Ferreira et al. 2006), MRI contrast agents (Fulton et al. 2006, Duimstra et al. 2005) and therapeutic agents (Krishnamurthy et al. 2008, Ott et al. 2005, Ma et al. 2005). M-C $\sigma$-bonded and M-C $\pi$-bonded organometallic complexes with sugar moieties also demonstrated biosensing and medicinal activity (Monney et al. 2013). According to present knowledge, sugar-containing M-C $\sigma$-bonded ethynyl complexes are scarce (Ma et al. 2005).

The authors report herein, the first example of sugar-containing $\mathrm{Pt}-\mathrm{C} \sigma$-bonded ethynyl complexes with tri-n-butylphosphine as auxiliary ligand. The antibacterial activities of the new sugar-containing acetylene ligand and its Pt- ethynyl complexes are evaluated.

\section{MATERIALS AND METHODS}

All solvents: dichloromethane $\left(\mathrm{CH}_{2} \mathrm{Cl}_{2}\right)$, diisopropylamine $\left({ }^{\mathrm{i}} \mathrm{Pr}_{2} \mathrm{NH}\right)$, tetrahydrofuran (THF), dimethylformamide (DMF), ethanol $\left(\mathrm{C}_{2} \mathrm{H}_{5} \mathrm{OH}\right)$, methanol $\left(\mathrm{CH}_{3} \mathrm{OH}\right)$, ethyl acetate (EtOAc), n-haxane $\left(\mathrm{C}_{6} \mathrm{H}_{14}\right)$, diethylether $\left(\mathrm{Et}_{2} \mathrm{O}\right)$, acetone $\left(\mathrm{CH}_{3} \mathrm{COCH}_{3}\right)$; and reagents: D- 
glucose, 4-iodoaniline, glacial acetic acid, trimethylsillyl acetylene, palladium acetate $\left(\mathrm{Pd}(\mathrm{OAc})_{2}\right)$, copper (I) iodide, triphenylphosphine $\left(\mathrm{PPh}_{3}\right)$, palladium(II)chloride, diethyl sulphide $\left(\mathrm{Et}_{2} \mathrm{~S}\right)$ trans-[Pt $\left.\left(\mathrm{P}(\mathrm{Bu})_{3}\right)_{2} \mathrm{Cl}_{2}\right]$, nutrient agar, beef extract, peptone, $\mathrm{NaCl}$, and standard antibiotic were purchased from Aldrich, Germany, and were used without further purification. Alumina (Aluminium oxide 90 active, neutral, 70-230 mesh ASTM) and silica gel (60G) for column chromatography were purchased from Merck, Germany.

Most of the reactions were performed under an inert atmosphere of nitrogen using standard techniques. Solvents were dried, distilled and degassed by nitrogen gas using standard procedure. Infrared spectra of all the compounds were recorded in FTIR spectrometer (Shimadzu: Prestige-21) using $\mathrm{KBr}$ (for solid) or dry $\mathrm{CH}_{2} \mathrm{Cl}_{2}$ (for liquid) as background and UV-Vis spectra were recorded in UV-Vis spectrophotometer (Shimadzu: UV-1800). Melting points of the products were determined on a melting point apparatus (Stuart SMP-10). Elemental analysis of sample was carried out at BCSIR laboratories, Dhaka, Bangladesh.

Synthesis of $N$-(4-iodophenyl)- $\beta$-D-glucopyranosylamine 1: 1 - 2 drops of glacial $\mathrm{AcOH}$ were added to a solution of D-glucose $(2 \mathrm{~g}, 0.010 \mathrm{~mol})$ and 4-iodoaniline $(2.21 \mathrm{~g}$, $0.010 \mathrm{~mol})$ in ethanol $(15 \mathrm{ml})$. The resulting solution was stirred at $60^{\circ} \mathrm{C}$ for $6 \mathrm{hrs}$ and concentrated to one third of its volume. The pale brown crystalline precipitate that was formed upon cooling was filtered off using sintered crucible, washed with cold isopropyl alcohol and water, and the crude product was purified by recrystallization from ethanol and $\mathrm{H}_{2} \mathrm{O}(3: 1)$ mixture. Pure pale brown solid was obtained in $85 \%$ yield (m.p. 113.8$\left.114.1^{\circ} \mathrm{C}\right)$. The product was highly soluble in acetone, ethanol, methanol, ${ }^{\mathrm{i}} \mathrm{PrNH}$ and DMF, but insoluble in $\mathrm{H}_{2} \mathrm{O}, \mathrm{CH}_{2} \mathrm{Cl}_{2}$ and n-hexane. IR $\left(v / \mathrm{cm}^{-1}\right): v(\mathrm{OH}$ and $\mathrm{N}-\mathrm{H}), 3600-$ 3077; v (aromatic C-H), 3014.74; v (C-H stretching of $\mathrm{CH}_{2}$ group), 2953.02, 2916.37, 2885.51 and 2850.79; $v$ (aromatic $\mathrm{C}=\mathrm{C}$ ), 1593.20, 1516.06 and 1485.19; $v$ (pyranose form of glycoside of the residue), 1020; $v$ ( $\beta \square \square$ configuration of the anomeric carbon), 881. Anal. Calc. for $\mathrm{C}_{12} \mathrm{H}_{16} \mathrm{INO}_{5} \cdot \mathrm{H}_{2} \mathrm{O}: \mathrm{C}, 36.11 ; \mathrm{H}, 4.55, \mathrm{~N}, 3.51 \%$. Found: $\mathrm{C}, 36.1 ; \mathrm{H}$, $4.53 ; \mathrm{N}, 3.38 \%$.

Synthesis of $N$-(4-trimethylsilylethynylphenyl)- $\beta$-D-glucopyranosylamine 2: To a freshly dried and degassed mixture of diisopropylamine $(20 \mathrm{ml})$ and dimethyl formamide $(14 \mathrm{ml})$ were added 1 (500 mg, $1.32 \mathrm{mmol})$, trimethylsilylactylene (312.97 $\mu \mathrm{l}, 2.23$ $\mathrm{mmol})$ and catalyst $\mathrm{Pd}(\mathrm{OAc})_{2}(5.92 \mathrm{mg}, 0.026 \mathrm{mmol}, 2 \mathrm{~mol} \%), \mathrm{PPh}_{3}$ (13 mg, 0.052 mmol, $2 \mathrm{~mol} \%)$, and $\mathrm{CuI}(5.027 \mathrm{mg}, 2 \mathrm{~mol} \%)$ with a positive flow of nitrogen, and the solution was stirred under inert atmosphere at $0{ }^{\circ} \mathrm{C}$. After $2 \mathrm{hrs}$, the reaction mixture was heated at $70^{\circ} \mathrm{C}$ temperature for $18 \mathrm{hrs}$. Then the reaction mixture was extracted by ethyl acetate and washed with saturated aqueous $\mathrm{NaHCO}_{3}$, brine and dilute $\mathrm{HCl}$ solution, then dried over anhydrous $\mathrm{MgSO}_{4}$. The solvent was removed under reduced pressure by a 
rotatory evaporator. The crude product was purified by silica column chromatography using $\mathrm{CH}_{2} \mathrm{Cl}_{2}$ and methanol as eluent. After removal of solvents under reduced pressure, the product was isolated as brick red paste in $68 \%$ yield. The product was highly soluble in acetone, ethanol, methanol, ${ }^{\mathrm{P}} \mathrm{PrH}$ and DMF, but insoluble in $\mathrm{H}_{2} \mathrm{O}, \mathrm{CH}_{2} \mathrm{Cl}_{2}$ and nhexane. IR $\left(v / \mathrm{cm}^{-1}\right): v(\mathrm{OH})$ and $v(\mathrm{NH}), 3673-3090 ; v$ (aromatic $\left.\mathrm{C}-\mathrm{H}\right), 3032.10,2958.80$; $v$ (alkyl group $\mathrm{C}-\mathrm{H}), 2926.01 ; v(\mathrm{C} \equiv \mathrm{C}), 2152.56 ; v(\operatorname{aromatic} \mathrm{C}=\mathrm{C}), 1654.92,1610.56$ and 1517.98; $v$ (pyranose form of glycoside of the residue), 1012; $v$ ( $\beta \square \square$ configuration of the anomeric carbon), 869. Anal. Calc. for $\mathrm{C}_{17} \mathrm{H}_{25} \mathrm{NO}_{5} \mathrm{Si} .3 .5 \mathrm{H}_{2} \mathrm{O}: \mathrm{C}, 49.26 ; \mathrm{H}, 7.78, \mathrm{~N}$, $3.38 \%$. Found: C, 49.2; H, 7.79; N, 3.96\%.

Synthesis of $N$-( $\beta$-D-glucopyranosyl) aniline-4-ethyne 3: To a solution of compound $2(109 \mathrm{mg}, 0.3090 \mathrm{mmol})$ in methanol $(6 \mathrm{ml}), \mathrm{K}_{2} \mathrm{CO}_{3}(85.41 \mathrm{mg}, 0.4635 \mathrm{mmol})$ was added. The reaction mixture was kept at room temperature for $18 \mathrm{hrs}$. After completion of the reaction, the crude product was obtained after removal of solvent in a rotatory evaporator. It was dissolved in ethyl acetate, washed with brine water and dried over $\mathrm{MgSO}_{4}$. The crude product was purified by silica column chromatography using $\mathrm{CH}_{2} \mathrm{Cl}_{2}$ and methanol as eluent. The pure product was obtained as a brick red paste in $68 \%$ yield. The product was highly soluble in acetone, ethanol, methanol, acetonitrile and THF, but insoluble in $\mathrm{H}_{2} \mathrm{O}, \mathrm{CH}_{2} \mathrm{Cl}_{2}, \mathrm{CHCl}_{3}$, and n-hexane. IR $\left(v / \mathrm{cm}^{-1}\right): v(\mathrm{NH}), v(\mathrm{OH})$ and $v(\equiv \mathrm{C}$ $\mathrm{H}), 3690-3077$; 3283.63; $v$ (aromatic $\mathrm{C}-\mathrm{H}), 3039.81 ; v\left(\mathrm{CH}_{2}\right.$ group), 2924.09 and 2889.37; $v(\mathrm{C} \equiv \mathrm{C}), 2100.48 ; v$ (aromatic $\mathrm{C}=\mathrm{C}), 1610.56,1519.91$ and 1417.68; $v$ (pyranose form of glycoside), 1012; $v$ ( $\beta \square \square$ configuration of the anomeric carbon), 900.

Synthesis of di[N-( $\beta$-D-glucopyranosyl) aniline-4 ethynylene]bis (tributylphosphine) platinum(II) 4 and 5: To a freshly dried and degassed mixture of diisopropylamine $(6 \mathrm{ml})$ and THF (12 ml), were added trans-dichlorobis (tributylphosphine) platinum (II) (50 mg, $0.088 \mathrm{mmol}$ ), ligand 3 (73 $\mathrm{mg}, 0.264 \mathrm{mmol}$ ) and catalytic amount of copper (I) iodide $(0.0046 \mathrm{mmol}, 0.92 \mathrm{mg}, 5 \mathrm{~mol} \%)$ with a positive flow of nitrogen. The reaction mixture was allowed to stir under refluxed at $65^{\circ} \mathrm{C}$ for $18 \mathrm{~h}$ under nitrogen atmosphere. During this period, the color of reaction mixture turned into yellow which was initially reddish in color. The formation of product was confirmed by taking IR spectroscopy. After completion of the reaction the solvent was removed under a reduced pressure. Product was purified by silica column chromatography. The first band, obtained by dichloromethane as eluant, was identified as mono-acetylide 4. The second fraction, obtained from the column using 4/1 dichloromethane/methanol, was identified as bisacetylide 5. After recrystallization from hexane, mono-acetylide 4 was isolated in $58 \%$ yield which was solid at $0^{\circ} \mathrm{C}$ and pale yellow oil at room temperature. Complex $\mathbf{5}$ was isolated as reddish yellow oil in $24 \%$ yield.

IR $\left(v / \mathrm{cm}^{-1}\right)$ of 4: $v(\mathrm{NH})$ and $v(\mathrm{OH}) 3600-3176.76 ; v$ (aromatic C-H), 3091.89; $v(\mathrm{C}-$ $\mathrm{H}$ stretching of aliphatic group), 2958.80-2858.51; $v$ (C $\equiv \mathrm{C}$ str. of mono Pt-acetylide), 
2117.84; $v$ (aromatic $C=C$ ), 1606.70, 1579.70 and 1400.32; $v$ (pyranose form of glycoside), 1062; $v$ ( $\beta \square \square$ configuration of the anomeric carbon), 910; $v$ (Pt-C), 501.49. Anal. Calc. for $\mathrm{C}_{38} \mathrm{H}_{70} \mathrm{ClNO}_{5} \mathrm{P}_{2} \mathrm{Pt} \bullet 1 / 2$ Hexane: C 51.48, H 8.11, N 1.46\%. Found: C, 51.2; H, 8.22; N, 2.37\%.

IR $\left(v / \mathrm{cm}^{-1}\right)$ of 5: $v(\mathrm{OH}), 3690-3100 ; v(\operatorname{aromatic} \mathrm{C}-\mathrm{H}), 3091.89 ; v(\mathrm{C}-\mathrm{H}$ stretching of aliphatic group), 2964.59, 2927.94 and 2835.36; $v(\mathrm{C} \equiv \mathrm{C}), 2083.12 ; v(\mathrm{C}=\mathrm{C}$ str. of aromatic ring), 1608.63, 1579.70 and 1400.32; $v$ (pyranose form of glycoside of the residue), 1016; $v$ ( $\beta \square \square$ configuration of the anomeric carbon), 904; $v(\mathrm{Pt}-\mathrm{C})$ 501.49. Anal. Calc. for $\mathrm{C}_{52} \mathrm{H}_{86} \mathrm{~N}_{2} \mathrm{O}_{10} \mathrm{P}_{2} \mathrm{Pt} \cdot 2 \mathrm{H}_{2} \mathrm{O}: \mathrm{C}, 52.38 ; \mathrm{H}, 7.61, \mathrm{~N}, 2.35 \%$. Found: C, 52.2; H, 7.88; $\mathrm{N}, 2.04 \%$.

Preparation of the culture media (bacteria solution): Bacterium was grown in nutrient broth which was prepared by mixing $0.15 \mathrm{~g}$ beef extract, $0.25 \mathrm{~g}$ peptone and $0.25 \mathrm{~g} \mathrm{NaCl}$ in $50 \mathrm{ml}$ of distilled water. The broth was heated for 15 minutes for complete dissolution, and was autoclaved for 15 minutes. Then single colony of Escherichia coli, Proteus penneri, Klebsiella oxytoca and Pseudomonas aeruginosa bacteria was added in $20 \mathrm{ml}$ broth separately and incubated at $37^{\circ} \mathrm{C}$ for $24 \mathrm{hrs}$.

Preparation of sample disk: A stock solution of $3 \mathrm{mg}-\mathrm{ml}^{-1}$ was made by dissolving the compound in distilled water. Paper discs of Whatman filter paper ( 0.45 micro pore) of uniform diameter $(5 \mathrm{~mm})$ and thickness $(1 \mathrm{~mm})$ were sterilized. 10 micro liters of stock solution $(30 \mu \mathrm{g}$ sample) were soaked in each disk.

Preparation of agar plates: The medium was made up by dissolving bacteriological nutrient agar $(3.2 \mathrm{~g})$ in $100 \mathrm{ml}$ distilled water. The mixture was autoclaved for $15 \mathrm{~min}$ at $120^{\circ} \mathrm{C}$, dispensed onto a sterilized Petri dish, allowed to solidify, and then used for inoculation.

Procedure of inoculation: Inoculation was done with the help of micropipette with sterilized tips; $25 \mu \mathrm{l}$ of activated strain was placed onto the surface of an agar plate, and spread evenly over the surface by means of a sterilized bent glass rod (Bell et al. 2009).

Application of disks: Sample disks and antibiotic disks were applied in of the each earlier inoculated agar plates and incubated at $37^{\circ} \mathrm{C}$ for $24 \mathrm{hrs}$. The zone of inhibition (diameter) was then measured (in $\mathrm{mm}$ ) around the sample and standard antibiotic disk. Antibiotic imipenem (IPM) was used against Escherichia coli, Proteus penneri and Klebsiella oxytoca bacteria and ciprofloxacin (CIP) was used against Pseudomonas aeruginosa bacteria as standard antibiotic disk. The antibacterial results of the compound were compared with the standard antibiotic disc. 


\section{RESULTS AND DISCUSSION}

Synthesis and characterization: The synthesis of D-glucose containing platinumcarbon $\sigma$-bonded ethynyl complexes $\mathbf{4}$ and $\mathbf{5}$ and their ethynyl precursor $\mathbf{3}$ is illustrated in scheme 1. Initially, hexose sugar-containing iodoaniline $\mathbf{1}$ was synthesized by glycosalylation reaction of D-glucose with 4-iodoaniline, in the presence of 1-2 drops of glacial acetic acid catalyst, in ethanol, at $60^{\circ} \mathrm{C}$, for 5-6 hrs (Wiebe et al. 2011). The pure pale brown product was isolated in $73 \%$ yield after recrystallization from ethanol and water. The trimethylsilyl protected ethynyl functional group was introduced into compound 1, using $\mathrm{Pd} / \mathrm{Cu}$ catalyzed cross-coupling reaction. Thus, the reaction between $\mathbf{1}$ and trimethylsilylacetylene, utilizing Sonagashira coupling route, gave compound $\mathbf{2}$ as viscous brick red oil in $68 \%$ yield. The removal of the silyl group by $\mathrm{K}_{2} \mathrm{CO}_{3}$ provided expected sugar-containing terminal acetylene 3 in $65 \%$ yield. Air and light sensitive terminal ethynyl compound $\mathbf{3}$ was a hard solid under vacuum, but becomes redish yellow paste when exposed to air.
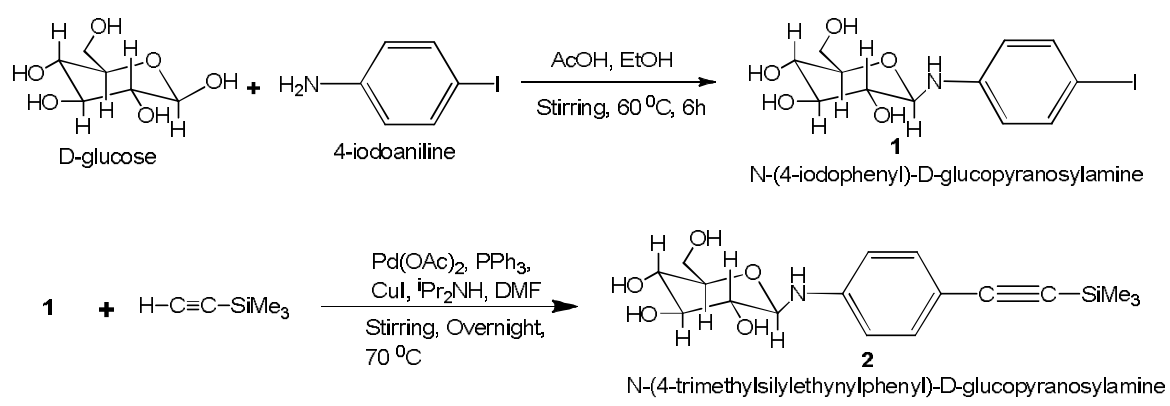

$2+\mathrm{K}_{2} \mathrm{CO}_{3}$
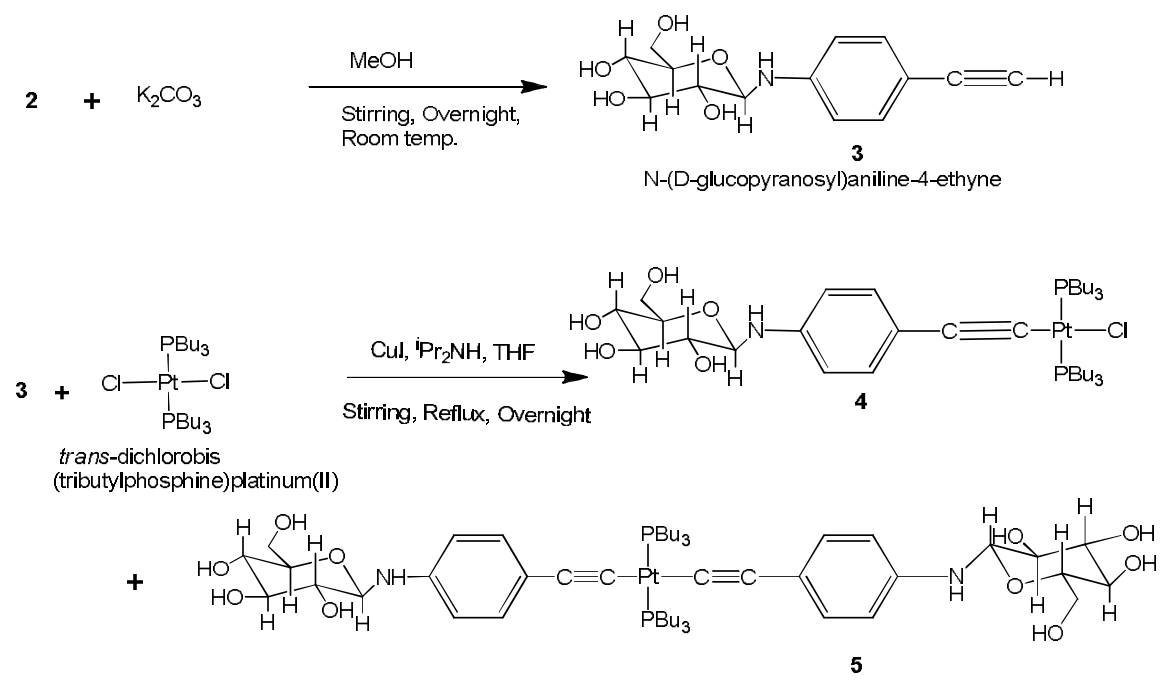

Scheme 1. Synthesis of compounds $\mathbf{1}, \mathbf{2}, \mathbf{3}, \mathbf{4}$ and 5. 
Dehydrohalogenation is an established route for the synthesis of M-C $\sigma$-bonded platinum ethynyl complexes (Long et al. 2003). Utilizing this route, using one equivalent of trans-dichlorobis(tributylphosphine)platinum(II) and 2.5 equivalent of ethynyl ligand 3 , in the presence of $\mathrm{CuI}$ catalyst, gave mono-ethynyl complex $\mathbf{4}$ as major product (58\% isolated yield). Though the bis-complex $\mathbf{5}$ was also formed, its isolated yield is only 20 $\%$. Dehydrogenation reaction always gives platinum bis-acetylide when ethynyl ligand is used in excess (Saha et al. 2005). Mono-acetylides of platinum is only obtained when platinum chloride precursor is used in excess under mild reaction condition (Zhou et al. 2009), sometimes even without catalyst (Amato et al. 2001). But when sugar substituted acetylene was used in this reaction, mono-substituted ethynyl complex was obtained as major product though the 2.5 equivalents ligand was used under elevated temperature. Both mono- and bis-ethynyl complex $\mathbf{4}$ and $\mathbf{5}$ were insoluble in water, but highly soluble in acetone, ethanol, methanol and dichloromethane.

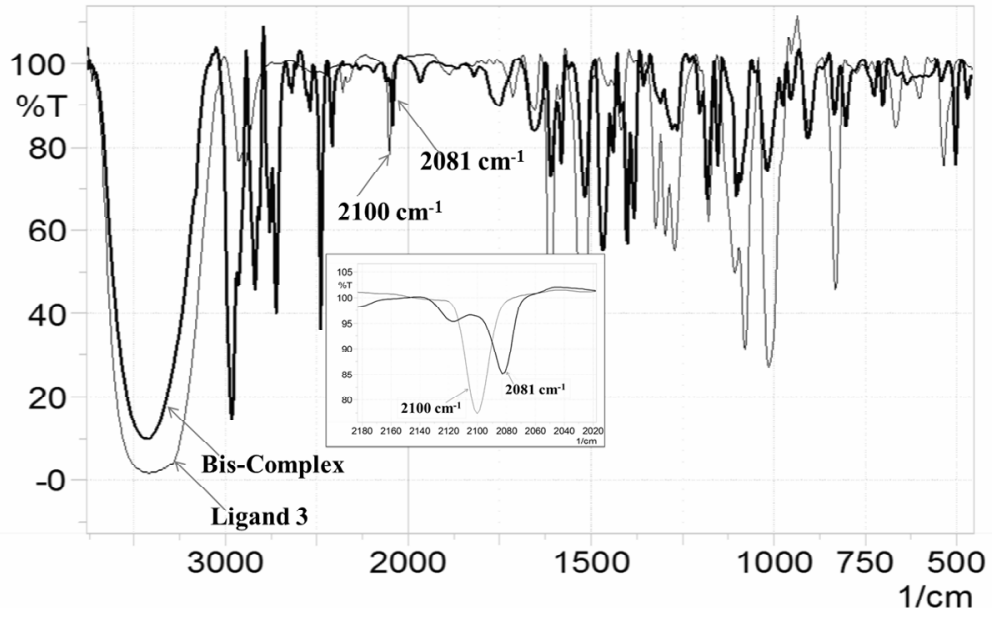

Fig. 1. IR (KBr) spectra of ligand $\mathbf{3}$ and bis-complex $\mathbf{5}$.

The composition and structures of compounds $\mathbf{2 - 5}$ were confirmed by elemental analysis (Table 1) and IR and UV-Vis spectroscopy (Figs 1, 2). The selected IR spectral data of all compounds are presented in Table 1. The compound $\mathbf{1}$ showed peak at 881 $\mathrm{cm}^{-1}$, suggesting the $\beta$-configuration of the anomeric carbon. The three peaks observed at $1020 \mathrm{~cm}^{-1}, 1053 \mathrm{~cm}^{-1}, 1068 \mathrm{~cm}^{-1}$ confirmed the pyranose form of the glycoside residue (Kulakov et al. 2008). In the IR spectrum of $\mathbf{2}$, a shift of these two groups of peaks was observed when iodide of $\mathbf{1}$ was replaced by trimethylsilylacetylene group. A new strong peak at $2152 \mathrm{~cm}^{-1}$ for the $(\mathrm{C} \equiv \mathrm{C})$ group, and a broad peak at 3361 for the $\mathrm{NH}$ and $\mathrm{OH}$ groups were observed in the spectrum of 2 . A shift of the $(\mathrm{C} \equiv \mathrm{C})$ stretching frequency from $2152 \mathrm{~cm}^{-1}$ to $2100 \mathrm{~cm}^{-1}$ was observed when the $\mathrm{Me}_{3} \mathrm{Si}$ group of the acetylene was 
replaced by the $\mathrm{H}$ in terminal ethynyl compound 3 . The stretching frequency of $(s p \mathrm{C}-\mathrm{H})$ is generally observed at around $3300 \mathrm{~cm}^{-1}$ for terminal acetylene which was obscured in the spectrum of 3 by the broad NH and $\mathrm{OH}$ band at $3200-3600 \mathrm{~cm}^{-1}$.

The IR spectrum of sugar substituted monoethynyl platinum complex $\mathbf{4}$ gave characteristic peaks at $2117 \mathrm{~cm}^{-1}$ for the $\mathrm{M}-\mathrm{C} \sigma$-bonded $(\mathrm{C} \equiv \mathrm{C})$ stretch and at $501 \mathrm{~cm}^{-1}$ for the (M-C) stretch. The stretching frequency of $(C \equiv C)$ is shifted from 2117 to $2081 \mathrm{~cm}^{-1}$ when the remaining chloride was replaced by the second acetylide group. The $\mathrm{M}-\mathrm{C}$ and $\mathrm{C} \equiv \mathrm{C}$ stretching frequencies are used to determine the geometry of the square planar metal ethynyl complexes (Sonogashira et al. 1978, Long et al. 2002, Saha et al. 2005).

Table 1. Selected IR and UV data and elemental analysis for compounds 1 - 5.

\begin{tabular}{|c|c|c|c|c|c|c|c|}
\hline \multirow[b]{2}{*}{ Compound } & \multicolumn{5}{|c|}{ Stretching frequency $\left(\mathrm{v} / \mathrm{cm}^{-1}\right)$} & \multirow{2}{*}{$\begin{array}{l}\text { Absorption } \\
\text { band } \\
\left(\lambda_{\max } / \mathrm{nm}\right)\end{array}$} & \multirow[b]{2}{*}{$\begin{array}{c}\text { Elemental } \\
\text { analysis }\end{array}$} \\
\hline & $\begin{array}{l}\text { OH str. } \\
\text { (broad } \\
\text { peak) of } \\
\text { glucose }\end{array}$ & $\begin{array}{l}\text { Aromatic } \\
\text { ring } \\
\text { C-H str. }\end{array}$ & $\begin{array}{c}\mathrm{C} \equiv \mathrm{C} \\
\text { str. }\end{array}$ & $\begin{array}{c}\equiv \mathrm{C}-\mathrm{H} \\
\text { str. }\end{array}$ & $\begin{array}{l}\text { Pt-C } \\
\text { str. }\end{array}$ & & \\
\hline 1 & $3600-3077$ & 3014 & $x$ & & & 252 & 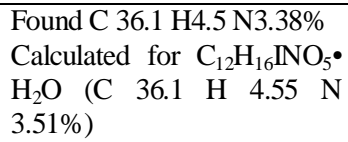 \\
\hline 2 & $3673-3090$ & 3032 & 2152 & & & 260 & $\begin{array}{l}\text { Found } \mathrm{C} \text { 49.2 H } 7.79 \mathrm{~N} \\
3.96 \% \text { Calculated for } \\
\mathrm{C}_{17} \mathrm{H}_{25} \mathrm{NO}_{5} \mathrm{Si} \cdot 3.5 \mathrm{H}_{2} \mathrm{O} \\
(\mathrm{C} 49.26 \mathrm{H} 7.78 \mathrm{~N} 3.38 \%)\end{array}$ \\
\hline 3 & $3690-3077$ & 3039 & 2100 & 3283 & & 271 & $\begin{array}{l}\text { Not satisfactory, as the } \\
\text { compound is air and light } \\
\text { sensitive }\end{array}$ \\
\hline 4 & $3600-3176$ & 3091 & 2117 & $x$ & $\begin{array}{l}542 \\
\text { and } \\
501\end{array}$ & 275 & $\begin{array}{l}\text { Found } \mathrm{C} \text { 51.2 H } 8.22 \mathrm{~N} \\
2.37 \% \text { Calculated for } \\
\mathrm{C}_{38} \mathrm{H}_{70} \mathrm{ClNO}_{5} \mathrm{P}_{2} \mathrm{Pt} \bullet 1 / 2 \\
\text { hexane }\end{array}$ \\
\hline 5 & $3690-3100$ & 3091 & 2081 & $x$ & $\begin{array}{l}542 \\
\text { and } \\
501\end{array}$ & 278 & $\begin{array}{l}(\mathrm{C} 51.48 \mathrm{H} 8.11 \mathrm{~N} 1.46 \%) \\
\text { Found C } 52.2 \mathrm{H} 7.88 \mathrm{~N} \\
2.04 \% \text { Calculated for } \\
\mathrm{C}_{52} \mathrm{H}_{86} \mathrm{~N}_{2} \mathrm{O}_{10} \mathrm{P}_{2} \mathrm{Pt} \cdot 2 \mathrm{H}_{2} \mathrm{O} \\
(\mathrm{C} 52.38 \mathrm{H} 7.61 \mathrm{~N} 2.35 \%)\end{array}$ \\
\hline
\end{tabular}

For example, cis- $\left[\left(\mathrm{PBu}_{3}\right)_{2} \mathrm{Pt}(\mathrm{C} \equiv \mathrm{C}-\mathrm{C} \equiv \mathrm{CH})_{2}\right]$ has a $\mathrm{C}_{2 \mathrm{v}}$ symmetry and showed two absorption bands for each $\mathrm{v}(\mathrm{C} \equiv \mathrm{C})$ and $\mathrm{v}(\mathrm{M}-\mathrm{C})$ (Sonogashira et al. 1978). In our case, only one absorption band for each of the $\mathrm{v}(\mathrm{C} \equiv \mathrm{C})$ and $\mathrm{v}(\mathrm{M}-\mathrm{C})$ was observed, suggesting that compound $\mathbf{4}$ and $\mathbf{5}$ have trans geometry around the platinum metal centre.

$\mathrm{UV}-\mathrm{Vis}$ spectroscopy is used to understand the $\pi$-interaction between the metal and ethynyl group in the metal ethynyl complexes (Saha et al. 2005, Younus et al. 1998, Fujikura et al. 1975). A broad band at 250-360 nm was observed in the spectrum of mono- and bis-ethynyl complex $\mathbf{4}$ and $\mathbf{5}$. Compared to the ethynyl compound $\mathbf{3}$, where 
little hump was merely seen, the bands of $\mathbf{4}$ and $\mathbf{5}$ were clearly visible. These bands have been assigned to the $\pi-\pi^{*}$ transition of the acetylenic fragment with LMCT character due to the mixing between $\pi^{*}(C \equiv C-R)$ and platinum $(n+1)$ p orbital. Similar spectroscopic features are reported in the related metal acetylide systems (Wong et al. 2004, Saha et al. 2005, Sina et al. 2015).

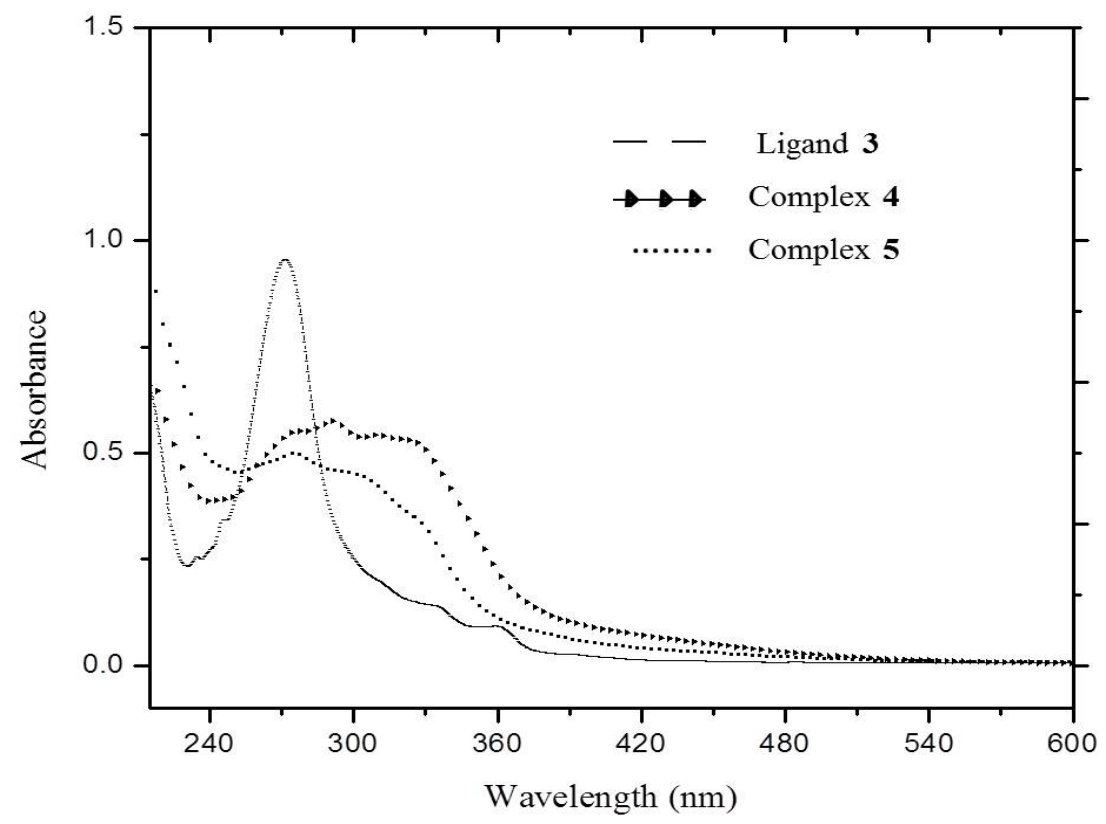

Fig. 2. UV-visible spectra of platinum complexes $\mathbf{4 , 5}$ and ligand $\mathbf{3}$.

Antibacterial activity: The antibacterial activities of sugar-containing iodo compound 1, ethynyl compounds $\mathbf{2}$ and $\mathbf{3}$, and platinum complexes $\mathbf{4}$ and $\mathbf{5}$ were tested against bacteria Escherichia coli, Proteus penneri, Klebsiella oxytoca and Pseudomonas aeruginosa. The results are presented in Table 2. Platinum ethynyl complexes $\mathbf{4}$ and $\mathbf{5}$ were resistant to all four bacteria, whereas its ethynyl ligand $\mathbf{3}$ was only resistant to Pseudomonas aeruginosa bacteria (Table 2, Fig. 3). The activity of $\mathbf{4}$ and $\mathbf{5}$ can be explained by the increase in lipophilic character due to the ligand attached to the platinum centre. The complex penetrates the lipid layer of the cell membrane, blocks the metal binding sites in the emzymes of microorganism. As a result, the metabolism in the cell is stopped, and microorganism dies (Dai et al. 2013). The anticancer and antibacterial activity of the gold ethynyl complexes were reported recently (Hikisz et al. 2015), and previous report (Ma et al. 2005) of the sugar-containing platinum ethynyl complexes demonstrated 100 times higher anticancer efficiency than cis platin. 
Table 2. Quantitative antibacterial assay results (inhibition zone as annular radii) of compounds 1-5 (agar nutrient, air, 35-37 ${ }^{\circ} \mathrm{C}, 48 \mathrm{hrs}$ ).

\begin{tabular}{ccccccccc}
\hline & \multicolumn{2}{c}{ Escherichia coli } & \multicolumn{2}{c}{ Proteus penneri } & Klebsiella Oxytoca & $\begin{array}{c}\text { Pseudomonas } \\
\text { aeruginosa }\end{array}$ \\
\cline { 2 - 8 } $\begin{array}{c}\text { Compound } \\
\text { name }\end{array}$ & $\begin{array}{c}\text { Disc } \\
\text { potency } \\
(\mu \mathrm{g})\end{array}$ & $\begin{array}{c}\text { Annular } \\
\text { radii after } \\
48 \mathrm{hrs} \\
(\mathrm{mm})\end{array}$ & $\begin{array}{c}\text { Disc } \\
\text { potency } \\
(\mu \mathrm{g})\end{array}$ & $\begin{array}{c}\text { Annular } \\
\text { radii } \\
\text { after } 48 \\
\text { hrs }(\mathrm{mm})\end{array}$ & $\begin{array}{c}\text { Disc } \\
\text { potency } \\
(\mu \mathrm{g})\end{array}$ & $\begin{array}{c}\text { Annular } \\
\text { radii after } \\
48 \mathrm{hrs} \\
(\mathrm{mm})\end{array}$ & $\begin{array}{c}\text { Disc } \\
\text { potency } \\
(\mu \mathrm{g})\end{array}$ & $\begin{array}{c}\text { Annular } \\
\text { radii after } \\
48 \mathrm{hrs} \\
(\mathrm{mm})\end{array}$ \\
\hline Antibiotic & 10 & 17 & 10 & 16 & 10 & 15 & 2.5 & 17 \\
& $(\mathrm{IPM})$ & & $(\mathrm{IPM})$ & & $(\mathrm{IPM})$ & & $(\mathrm{CIP})$ & \\
1 & 30 & 7 & 30 & 8 & 30 & 8 & 30 & 6 \\
2 & 30 & 7 & 30 & 8 & 30 & $\times$ & 30 & 6 \\
3 & 30 & $\times$ & 30 & $\times$ & 30 & $\times$ & 30 & 5 \\
5 & 30 & 4 & 30 & 5 & 30 & 4 & 30 & 4 \\
4 & 30 & 5 & 30 & 4 & 30 & 4 & 30 & 5 \\
\hline
\end{tabular}

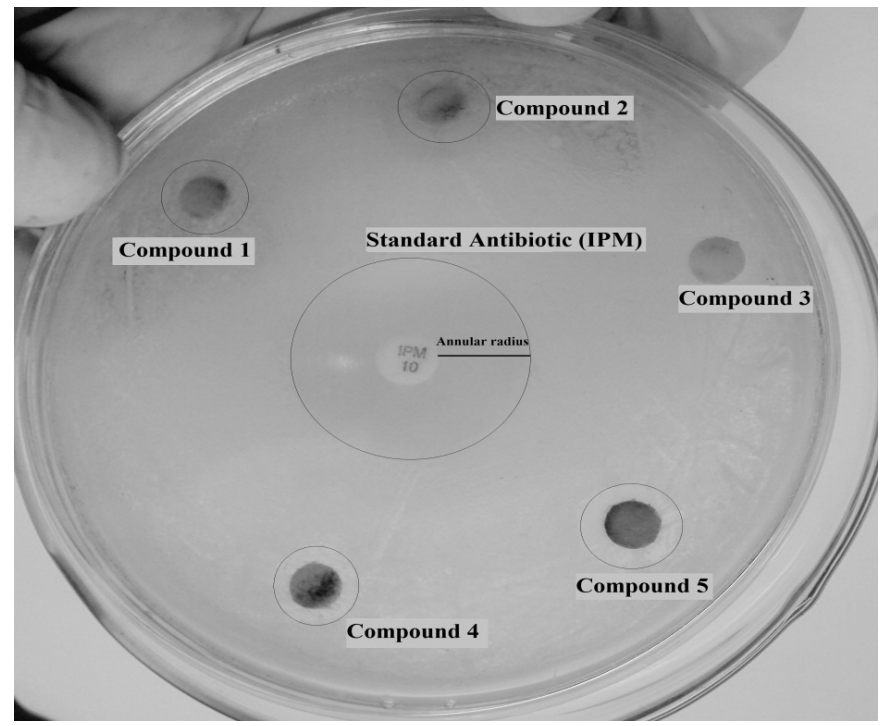

Fig. 3. Antibacterial activity of compounds 4, 5 against Escherichia coli in the form of inhibition zone.

Hexose sugar-containing aryl ethynyl ligand $\mathbf{3}$ was formed by Sonogashira coupling reaction using $\mathrm{N}$-(4-iodophenyl)- $\beta$-D-glucopyranosylamine $\mathbf{1}$ and trimethysilylacetylene, followed by the deprotection of trimethylsilyl group by $\mathrm{K}_{2} \mathrm{CO}_{3}$. Sugar-containing transition metals acetylide complexes $\mathbf{5}$ and $\mathbf{4}$ were synthesized by the dehydrohalogenation reaction between trans- $\left[\mathrm{Pt}\left(\mathrm{P}(\mathrm{Bu})_{3}\right)_{2} \mathrm{Cl}_{2}\right]$ and ligand 3 in presence of $\mathrm{CuI}$ catalyst. The new products were fairly stable in air, and soluble in organic solvents. The compounds, 1 - 5 were characterized by IR, UV-Vis spectroscopy and elemental analysis. The antibacterial activities the compounds were studied by disc diffusion method. 


\section{ACKNOWLEDGEMENTS}

The authors would like to thank University Research Center, Shahjalal University of Science and Technology, Sylhet-3114 and Higher Education Quality Enhancement Project (HEQEP), UGC, Bangladesh for financial support.

\section{REFERENCES}

Amato, R. D., A. Furlani, M. Colapietro, G. Portalone, M. Casalboni , M. Falconieri and M. V. Russo. 2001. Synthesis, characterization and optical properties of symmetrical and unsymmetrical $\mathrm{Pt}(\mathrm{II})$ and $\mathrm{Pd}(\mathrm{II})$ bis-acetylides. Crystal structure of trans- $\left[\mathrm{Pt}\left(\mathrm{PPh}_{3}\right)_{2}(\mathrm{C} \equiv \mathrm{C}-\right.$ $\left.\mathrm{C}_{6} \mathrm{H}_{5}\right)\left(\mathrm{C} \equiv \mathrm{C}-\mathrm{C}_{6} \mathrm{H}_{4} \mathrm{NO}_{2}\right)$ ]. J. Organomet. Chem. 627: 13-22.

Babudri, F., D. Colangiuli, P. A. Di Lorenzo, G. M. Farinola, O. H. Omar and F. Naso. 2003. Synthesis of poly(aryleneethynylene)s bearing glucose units as substituents. Chem. Commun. 130-131.

Bell, S. M., J. N. Pham and I. W. Carter. 2009. Antibiotic Susceptibility Testing by the CDS Method. $\left(5^{\text {th }}\right.$ Ed.). South Eastern Area Laboratory Services, Randwick, Australia.

Bunz, U. H. F. 2009. Poly(aryleneethynylene)s. Macromol. Rapid Commun. 30: 772-805.

Dai, C. H. and F. L. Mao. 2013. Structure of a new schiff base cobalt (III) complex with antibacterial activity. J. Struct. Chem. 54: 624-629.

Dam, T. K. and C. F. Brewer. 2002. Thermodynamic studies of lectin-carbohydrate interactions by isothermal titration caloarimetry. Chem. Rev. 102: 387-429.

Disney, M. D., J. Zheng, T. M. Swager and P. H. Seeberger. 2004. Detection of bacteria with carbohydrate-functionalized fluorescent polymers. J. Am. Chem. Soc. 126: 133-43.

Duimstra, J. A., F. J. Femia and T. J. Meade. 2005. A Gadolinium Chelate for Detection of $\hat{a}-$ Glucuronidase: A Self-Immolative Approach. J. Am. Chem. Soc. 127: 12847-12855.

Erdogan, B., J. N. Wilson and U. H. F. Bunz. 2002. Synthesis and mesoscopic order of a sugar-coated poly( $p$-phenyleneethynylene). Macromolecules 35: 7863-7864.

Ferreira, C. L., C. B. Ewart, S. R. Bayly, B. O. Patrick, J. Steele, M. J. Adam and C. Orvig. 2006. Glucosamine conjugates of tricarbonylcyclopentadienyl rhenium(I) and technetium(I) cores. Inorg. Chem. 45: 6979-6987.

Fujikura, Y., K. Sonogashira and N. Hagihara. 1975. Preparation and UV spectra of some oligomer-complexes composed of platinum group metals and conjugated poly-yne systems. Chem. Lett. 4: 1067-1070.

Fulton, D. A., E. M. Elemento, S. Aime, L. Chaabane, M. Bottad and D. Parker. 2006.Glycoconjugates of gadolinium complexes for MRI applications. Chem. Commun. 10641066.

Gottschaldt, M. and U. S. Schubert. 2009. Prospects of metal complexes peripherally substituted with sugars in biomedicinal applications. Chem. Eur. J. 15: 1548-1557.

Gottschaldt, M., R. Wegner, H. Gçrls, P. Klfers, E. G. Jger, and D. Klemm. 2004. Binuclear copper (II) complexes of 5- $N$-( $\beta$-ketoen)amino-5-deoxy-1, 2- $O$-isopropylidene- $\alpha$ - $d$-glucofuranoses : synthesis, structure, and catecholoxidase activity. Carbohydr. Res. 339: 1941-1952.

Hikisz, P., L. Szczupak, A. K. Chyła, A. Guspiel, L. Oehninger, I. Ott, B. Therrien, J. Solecka and K. Kowalski. 2015. Anticancer and antibacterial activity studies of gold (I)-alkynyl chromones. Molecules 20: 19699-19718.

Kim, I. B., H. Shin, A. J. Garcia and U. H. F. Bunz. 2007. Use of a folate-ppe conjugate to image cancer cells in vitro. Bioconjugate Chem. 18: 815-820. 
Krishnamurthy, D., M. R. Karver, E. Fiorillo, V. Orru, S. M. Stanford, N. Bottini and A. M. Barrios. 2008. Gold(I)-mediated inhibition of protein tyrosine phosphatases: a detailed in vitro and cellular study. J. Med. Chem. 51: 4790-4795.

Kulakov, I. V., A. I. Ilin, Z. A. Kabyl and A. M. Gazaliev. 2008. Synthesis of $\beta$ D_glucopyranosyl and $\beta$-D-galactopyranosylamines from 4-bromo-3-methylaniline and 2-amino-5bromopyridine. Russ. Chem. Bull. Int. Ed. 57: 2443-2445.

Long, N. J., A. J. P. White, D. J. Williams and M. Younus. 2002. Synthesis and characterisation of new platinum ethynyl dimers and polymers with pendant ferrocenyl groups. J. Organomet. Chem. 649: 94-99.

Long, N. J. and C. K. Williams. 2003. Metal alkynyl $\sigma$ complexes: synthesis and materials. Angew. Chem. Int. Ed. 42: 2586-2617.

Ma, D. L., T. Y. T. Shum, F. Zhang, C. M. Che and M. Yang. 2005. Water soluble luminescent platinum terpyridine complexes with glycosylated acetylide and arylacetylide ligands: photoluminescentproperties and cytotoxicities. Chem. Commun. 4675-4677.

Mindt, T. L., H. Struthers, L. Brans, T. Anguelov, C. Schweinsberg, V. Maes, D. Tourwe and R. Schibli. 2006. "Click to Chelate": Synthesis and installation of metal chelates into biomolecules in a single step. J. Am. Chem. Soc. 128: 15096-15097.

Monney A. and M. Albrecht. 2013. Transition metal bioconjugates with an organometallic link between the metal and the bimolecular scaffold. Coord. Chem. Rev. 257: 2420-2433.

Ott, I., T. Koch, H. Shorafa, Z. Bai, D. Poeckel, D. Steinhilberb and R. Gust. 2005. Synthesis, cytotoxicity, cellular uptake and influence on eicosanoid metabolism of cobalt-alkyne modified fructoses in comparison to auranofin and the cytotoxic COX inhibitor Co-ASS. Org. Biomol. Chem. 3: 2282-2286.

Phillips, R. L., I. B. Kim, L. M. Tolbert and U. H. F. Bunz. 2008. Fluorescence self-quenching of a mannosylatedpoly( $p$-phenyleneethynylene) induced by concanavalin A. J. Am. Chem. Soc. 130: 6952-6954.

Saha, R., M. A. Qaiunm, D. Debnath, M. Younus, N. Chawdhury, N. Sultana, G. Kociok-Koon, L. Ooi, P. R. Raithby and M. Kijima, 2005. A new series of luminescent phosphine stabilised platinum ethynyl complexes. Dalton Trans. 2760-2765.

Sina, A. A. I., S. M. I. Al-Rafia, M. F. Ahmad, R. K. Paul, S. M. S. Islam, M. Younus and W. Y. Wong. 2015. Synthesis, structures and properties of novel platinum (II) acetylide complexes and polymers with tri(tolyl)phosphine as the $\sigma$ auxiliary ligand. J. Inorg. Organomet. Polym. 25: 427-436.

Sonogashira, K., Y. Fujikura, T. Yatake, N. Toyoshima, S. Takahashi and N. Hagihara. 1978. Syntheses and properties of cis- and trans-dialkynyl complexes of platinum(II). J. Organomet. Chem. 145: 101-108.

Steinborn, D. and H. Junicke, 2000. Carbohydrate complexes of platinum-group metals. Chem. Rev. 100: 4283-4317.

Wegner, R., M. Gottschaldt, H. Gçrls, E.-G.Jger and D. Klemm. 2001. Copper(II) complexes of aminocarbohydrate $\beta$-ketoenaminic ligands: efficient catalysts in catechol oxidation. Chem. Eur. J. 7: 2143-2157.

Wiebe, C., C. Schlemmer, S. Weckab and T. Opatz. 2011. Sweet (hetero) aromatics: glycosylated templates for the construction of saccharide mimetics. Chem. Commun. 47: 9212-9214.

Wong, K. M. C., W. S. Tang, B. W. K. Chu, N. Zhu and V. W. W. Yam. 2004. Synthesis, photophysical properties, and biomolecular labeling studies of luminescent platinum (II)terpyridyl alkynyl complexes. Organometallics 23: 3459-3465. 
Yang, C. Y. J., M. Pinto, K. Schanze and W. H. Tan. 2005. Direct synthesis of an oligonucleotidepoly-(phenyleneethynylene) conjugate with a precise one-to-one molecular ratio. Angew. Chem. 117: 2628-2632.

Younus, M., N. J. Long, P. R. Raithby, J. Lewis, N. A. Page, A. J. P. White, D. J. Williams, M. C. B. Colbert, A. J. Hodge, M. S. Khan and D. G. Parker. 1999. Synthesis and characterisation of mono-acetylide and unsymmetrical bis-acetylide complexes of ruthenium and osmium: $\mathrm{X}$-ray structure determinations on $\left[(\text { dppe })_{2} \mathrm{Ru}(\mathrm{Cl})\left(\mathrm{C} \equiv \mathrm{C}-\mathrm{C}_{6} \mathrm{H}_{4}-p-\mathrm{NO}_{2}\right)\right]$, $\left[(\mathrm{dppe})_{2} \mathrm{Ru}(\mathrm{Cl})\left(\mathrm{C} \equiv \mathrm{C}-\mathrm{C}_{6} \mathrm{H}_{3}-\right.\right.$ $\left.\left.o-\mathrm{CH}_{3}-p-\mathrm{NO}_{2}\right)\right]$ and $\left[(\mathrm{dppm})_{2} \mathrm{Os}\left(\mathrm{C} \equiv \mathrm{C}-\mathrm{C}_{6} \mathrm{H}_{4}-p-\mathrm{CH}_{3}\right)\left(\mathrm{C} \equiv \mathrm{C}-\mathrm{C}_{6} \mathrm{H}_{4}-p-\mathrm{NO}_{2}\right)\right]$. J. Organomet. Chem. 578: 198-209.

Zhou, B. G., W. Y. Wong, S. Y. Poon, C. Ye and Z. Lin. 2009. Symmetric versus unsymmetric platinum(II) bis(aryleneethynylene)s with distinct electronic structures for optical power limiting/optical transparency trade-off optimization. Adv. Funct. Mater. 19: 531-544.

(Received revised manuscript on 6 April, 2016) 